\title{
Radical change and dietary conservatism: Mixing model estimates of human diets along the Inner Asia and China's mountain corridors
}

Xinyi Liu, ${ }^{1 *}$ Rachel E. B. Reid, ${ }^{1}$ Emma Lightfoot, ${ }^{2}$ Giedre Motuzaite Matuzeviciute ${ }^{3}$ and Martin K. Jones ${ }^{2}$

${ }^{1}$ Department of Anthropology, Washington University in St. Louis, One Brookings Drive, St. Louis, MO 63130, USA

2 McDonald Institute for Archaeological Research, University of Cambridge, Downing Street, Cambridge, CB2 3ER, UK

${ }^{3}$ Department of Archaeology, Vilnius University, Universiteto 7, Vilnius 01513, Lithuania

*Corresponding author

Email address: liuxinyi@wustl.edu (X. Liu)

\begin{abstract}
Recent research has demonstrated that a series of mountains from the eastern Iranian Plateau to eastern Kazakhstan and to western China played a significant role in trans-Eurasian exchange during the third and second millennia BC. In close association with these mountain corridors, a number of southwestern Asian cereals, notably free threshing wheat and barley, moved eastward; broomcorn millet, among other plant foods originating in China, moved westwards. In this paper we apply Bayesian stable isotope mixing models to published and newly obtained isotopic data in order to quantitatively estimate the contribution of different food resources to human diets; and we consider the complexity of human food strategies at the both ends of these mountain corridors: southern Kazakhstan and the Hexi corridor in western China. Our results contrast the rapid adoption of wheat and/or barley in the Hexi Corridor with the gradual, incremental adoption of millet in southern Kazakhstan during the second millennium BC.
\end{abstract}




\section{Key words}

isotopes, mixing model, millet, wheat, barley, mountain corridor

\section{Introduction}

In recent years, our knowledge and understanding of the nature of the connections among groups of people in the Bronze Age Eurasia has grown. Various studies consider not only the expansion of food technologies, but also the spread of the ways that food was consumed in prehistory. That is, why human diets in some areas were subject to radical changes while in other areas people appear to have been conservative in their dietary habits (Boivin et al., 2012; Lightfoot et al., 2013; Liu and Jones, 2014; Liu et al., 2014). In the context of this discussion, the eastern sector of Central Asia is of particular interest. Research has demonstrated that a series of foothill sites from the eastern Iranian Plateau to eastern Kazakhstan form an 'Inner Asian Mountain Corridor' which played a significant role in trans-Eurasian exchange during the third and second millennia BC (Frachetti et al., 2010; Frachetti, 2012; Spengler and Willcox, 2013; Spengler et al., 2014a; Spengler et al., 2014b; Motuzaite Matuzeviciute et al., 2015b; Spengler 2015). Other scholars have extended this mountain corridor concept to consider broadly the foothills of the Tianshan Mountains, as well as the northern edges of the Tibetan Plateau, namely the Hexi corridor, and the western loess plateau in China (Flad et al., 2010; Chen et al., 2014; Liu et al., 2014; Zhang et al., 2015; Liu et al., in press).

There is now much evidence that a series of connections between human populations was established through these mountain corridors since the Bronze Age. From the evidence of early horse management, metallurgy and a range of associated artifacts, we can trace the origins of these connections to the latter part of the second millennium BC (Levine, 1999; Mei, 2003; Sherratt, 2005; Frachetti, 2008; Linduff and Mei, 2009; Rawson, 2013; Lin, 2015). Archaeobotanical evidence from cereal crops may be able to push the date of these connections back even 
further into at least the third millennium $\mathrm{BC}$ or earlier. This process has been referred as 'food globalisation in prehistory' (e.g. Jones et al., 2011; Jones et al., in press). In close association with these mountain corridors, a number of southwestern Asian cereals, notably free threshing wheat and barley, moved eastward; broomcorn millet, among other plant foods originating in China, moved westwards (see Motuzaite Matuzeviciute et al., 2013; Spengler et al., 2014b; Liu et al., in press for reviews). Both Chinese and southwest Asian cereals were documented in the late third millennium BC in Begash in east Kazakhstan (directly dated, 2461-2154 cal. BC), while a number of sites from west China provide similar evidence dated to the late third and early second millennium BC (2100-1800 cal. BC) (Frachetti et al., 2010; Liu et al., in press).

While the archaeobotanical evidence provides locations, dates and site contexts, it stops short of elucidating the significance of the trans-located crops in contemporary human food chains. However, stable carbon and nitrogen isotopic evidence allows us to quantify the dietary proportions of foodstuffs with different isotopic ratios. It so happens that two of the crops moving westward from China (broomcorn and foxtail millet) are $\mathrm{C}_{4}$ plants that leave an isotopic signature throughout the food chain which is distinctive from that left by southwest Asian crops moving eastward (which are all $\mathrm{C}_{3}$ plants). A number of recent isotope studies follow the movements in both directions by investigating possible human diets. These studies have demonstrated that the westward expansion of Chinese millets, and the eastward movement of the Fertile Crescent cereals follow different isotopically detectable patterns (Lightfoot et al., 2014; Motuzaite Matuzeviciute et al., 2015a). Other studies have addressed such questions as: why a new type of cereal could be adopted in a region with an already existing indigenous cereal cultivation tradition; and why a new type of cereal was welcomed in one region but rejected initially in another (Lightfoot et al., 2013; Liu et al., 2014). In this paper, we apply Bayesian stable isotope mixing models to previously published and newly obtained isotopic data in order to quantitatively estimate the contribution of different food resources to human diets. In the light of recent isotope studies, we 
consider the driving force(s) behind the expansions of these cereal crops; and we consider the complexity of human food strategies at the both ends of the mountain corridors: southern Kazakhstan and the Hexi Corridor in northwest China.

\section{Expansions of the Fertile Crescent crops and the Chinese millets}

By c. $1500 \mathrm{BC}$, the geographical range of two of the southwest Asian crops, free threshing wheat and barley, and of one of the North China's domesticates, broomcorn millet, extended from the Pacific to the Atlantic Ocean. The chronology, pathways, and driving forces of these expansions have been subjected to scholarly investigations (e.g. Jones et al. 2011).

The pattern of the eastern movement of wheat and barley from southwest Asia has recently become clear. Evidence for the cultivation and domestication of various wheat and barley species appears in southwest Asia from at least 10,000 years ago (e.g. Weiss and Zohary 2011). Various forms of wheat and barley are recorded in western Central Asia around 6000-5000 years ago (Miller, 2003; Harris, 2010) and in Pakistan by around 7000 years ago (Costantini, 1984; Meadow, 1996; Petrie, 2015). After these initial spreads, the subsequent, more extensive movement of wheat and barley appears to be restricted to the free threshing forms. Research in eastern Central Asia and western China shows the mountain corridors played an important role in expansion of free threshing wheat during the third millennium BC (see Liu et al. in press for a review).

Beyond Central Asia, we can distinguish two separate expansion sequences of free threshing wheat to the north and south of the Tibetan Plateau in the third and the second millennium BC (Liu et al., in press). In the north, the sequence runs from the eastern range of the Inner Asian Mountain Corridor through the Tianshan Mountains and the Hexi Corridor. It then extends to the middle and lower reaches of the Yellow River. In the south, a second sequence may be inferred from the Indus and northwest India through to South India and the Ganges region. The source of 
free threshing wheat in Tibet could be from either the northern or the southern corridor. The pathway by which barley spread east is less constrained. It is likely that the spread of barley was associated with the movement of free threshing wheat, but perhaps barley spread at different rates along the northern and southern routes.

The earliest sites with broomcorn and foxtail millet in northern China before 5000 $\mathrm{BC}$ are patchily distributed along foothills at the margins of the loess plateau (e.g. Liu et al., 2009; Yang et al., 2012; Liu et al., 2015). The subsequent two millennia (5000-3000 BC) sees a high concentration of millet sites on the Loess Plateau, particularly along the valleys of the Wei River and its tributaries (Wagner et al., 2012). Broomcorn millet expanded westward to east Kazakhstan (Frachetti et al., 2010) in the late third millennium BC. It remains unclear, however, how broomcorn millet got to Europe from Central Asia. Foxtail millet, on the other hand, expanded to southwest and southeast China during the third millennium BC. Evidence of foxtail millet is documented in Taiwan, Thailand and India during the second millennium BC (Webber, 1991; Webber, 2001; Castillo, 2011). An enigmatic feature of the records for broomcorn millet is its earliest apparent occurrence on both sides of the Old World at the same time. During the sixth and fifth millennia BC, some twenty sites from Europe and the Caucasus report broomcorn millet identified to species level (Hunt et al., 2008). However, attempts to directly date some of these fifth/sixth millennium BC millets have shown that they date to the Late Bronze Age and later periods, therefore the date at which Asian millets reached Europe remains a matter for enquiry and ratification (Motuzaite Matuzeviciute et al., 2013).

\section{Dietary shifts in Kazakhstan and China}

Recent works have revealed dietary patterns for the broader eastern Central Asia and western China during the Bronze and Iron Ages (Guan et al., 2007; Zhang et al., 2010; Zhang and Zhu, 2011; Shishlina et al., 2012; Lightfoot et al., 2013; Ma et al., 2013a; Ma et al., 2013b; Murphy et al., 2013; Svyatko et al., 2013; Lightfoot et al., 2014; Liu et al., 2014; Ventresca Miller et al., 2014; Motuzaite Matuzeviciute et al., 
2015a; Zhou and Garvie-Lok, 2015). Of particular interest to this paper, dietary changes are documented on both sides of the mountain corridors around 4000 years ago in southern Kazakhstan and in the Hexi corridor of western China (Lightfoot et al., 2014; Liu et al., 2014; Motuzaite Matuzeviciute et al., 2015a). In seven cemetery sites studied by Liu and colleagues (2014), carbon isotope data cluster individual skeletons into two distinct groups. The individuals in one group correspond to a diet dominated by $\mathrm{C}_{4}$ plants (millet), while those in the other group correspond to a mixed diet containing $\mathrm{C}_{3}$ and $\mathrm{C}_{4}$ resources, most likely wheat and/or barley and millet, respectively. The first of these groups comprises all of the individuals from two sites dating to before $c .1900 \mathrm{BC}$. The second group comprises virtually all of the individuals from five sites dating to after 1900 BC. It would appear that all of the individuals sampled at each site shared a common dietary pattern. There are no evident 'trail-blazers' in the novel post-1900 BC pattern. Liu and colleagues (2014) inferred that this considerable agrarian shift was a 'bottomup' change, rather than an elite led process. The 'tidal wave' of western crops after 1900 BC clearly corresponded to an agricultural revolution in the Hexi corridor. It should be noted that these burials from the Hexi corridor were from seemingly public cemeteries, presumably representing a cross-section of society. This is different from the kurgans in Central Asia which may represent elite burials.

A similar dietary shift has been observed at the other end of the mountain corridors, that is the southern part of Kazakhstan. Work done by Motuzaite Matuzeviciute and colleagues (2015a) showed that $\mathrm{C}_{4}$ plants became established food sources in southern Kazakhstan from the Middle-Late Bronze Age onwards (c. 1800 BC), and were likely eaten directly by humans, while there is no such evidence in northern Kazakhstan. Given the archaeobotanical evidence from eastern Central Asia, it is reasonable to attribute the $\mathrm{C}_{4}$ signal to the consumption of millet(s). Such evidence constitutes the earliest-to-date directly dated isotopic signals of millet consumption outside of China (Motuzaite Matuzeviciute et al., 2015a). The isotopic data from southern Kazakhstan indicate that while millet(s) was a significant dietary 
component for a number of individuals, it is possible that they were not staple foods in the Bronze Age as they were in the Iron Age.

Carbon and nitrogen isotope values measured in bone collagen are primarily derived from dietary protein (Hare et al., 1991; Ambrose and Norr, 1993; Jim et al., 2006). When human consumption of animal protein is relatively high, collagen isotopic values likely fail to capture isotopic signatures from relatively lowerprotein, carbohydrate-rich cereal crops, such as millet, wheat and barley. However, in the context of naturally isotopically labeled food resources - for example $\mathrm{C}_{4}$ based carbohydrate source (millets) and $\mathrm{C}_{3}$ based protein source (meat fed on $\mathrm{C}_{3}$ plants) consideration of the diversity of food inputs (both plant and animal) of a given community becomes plausible. In the following section we apply the Bayesian stable isotope mixing model Stable Isotope Analysis in R (SIAR - R package 'simmr' version 0.2 to published and newly obtained $\delta^{13} \mathrm{C}$ and $\delta^{15} \mathrm{~N}$ data from human and animal bone collagen and carbonised plant remains in order to quantify the contribution of different food protein resources to human diets at six Bronze Age and Iron Age sites in southern Kazakhstan and the Hexi corridor in China.

\section{Material and methods}

We sourced carbon and nitrogen isotope data for humans, animals and plants from the literature. All data from Kazakhstan are previously published (Motuzaite Matuzeviciute et al., 2015a). Isotopic results from human specimens from China have also been published by (Liu et al., 2014). Results of isotope analyses for Chinese animal and plant remains are published here for the first time. These samples are from three sites in Gansu province in west China: Xihetan, Huoshaogou and Sanbadongzi. Procedures for sampling and analysis follow those described in Liu (et al., 2014). Site information and isotope results are summarized in Table 1 and 2. Site locations are shown in Figure 1. 
To quantify the proportional contributions of various plant and animal food sources to the assimilated dietary protein of archaeological humans, we used Stable Isotope Analysis in R (SIAR - R package 'simmr' version 0.2) (Parnell et al., 2010). We followed the best practices for stable isotope mixing models as delineated by Phillips and colleagues (2014). SIAR is a Bayesian stable isotope mixing model that is capable of accounting for error in estimates of discrimination factors (i.e. the difference in isotopic composition between an individual's tissue and diet: $\Delta^{13} C_{\text {diet- }}$ collagen and $\Delta{ }^{15} N_{\text {diet-collagen }}$ ), variation in source isotopic values, and different food source elemental concentrations of $\mathrm{C}$ and $\mathrm{N}$.

When diets include both plant and animal resources, which have very different C and $\mathrm{N}$ concentrations, failure to employ a concentration-weighted model can significantly impact upon results (Phillips and Koch, 2002). We calculated digestible $[\mathrm{C}]$ and $[\mathrm{N}]$ of human foods from the USDA Nutrient Database following the calculations presented in Koch and Phillips (2002). To avoid a severely underdetermined model, we grouped logically related resources (e.g. domestic animals) a priori when their average isotope values were similar; for example, at Kainar-Bulak I we combined sheep and/or goat $\left(n=11 ; \delta^{13} \mathrm{C}:-23.2 \pm 0.6 \%\right.$ o, $\delta^{15} \mathrm{~N}: 7.7$ $\pm 1.2 \%$ ), cattle $\left(\mathrm{n}=4 ; \delta^{13} \mathrm{C}:-22.7 \pm 0.8 \%\right.$ o, $\left.\delta^{15} \mathrm{~N}: 8.1 \pm 0.8 \%\right)$ and horse $\left(\mathrm{n}=4 ; \delta^{13} \mathrm{C}\right.$ : $-23.4 \pm 1.2 \%$, $\left.\delta^{15} \mathrm{~N}: 6.7 \pm 1.8 \% 0\right)$ into one domestic animal food source $\left(\delta^{13} \mathrm{C}:-23.1\right.$ $\pm 0.8 \%, \delta^{15} \mathrm{~N}: 7.6 \pm 1.3 \%$ ). The isotopic values of the food sources considered at each site were determined from animal and plant remains found in the same or adjacent contemporaneous sites wherever possible. To account for systematic dietto-collagen isotopic difference we used a $\Delta^{13} C_{\text {diet-collagen value of } 5 \pm 1 \% \text { and a }}$ $\Delta^{15} \mathrm{~N}_{\text {diet-collagen }}$ of 4-5 $\pm 1 \%$. These values are within the average range used in previous palaeodiet studies (Schoeninger, 1985; Lee-Thorp et al., 1989; Ambrose and Norr, 1993; Newsome et al., 2004; Hedges and Reynard, 2007). Discrimination factors are also influenced by the isotopic compositions of dietary macronutrients (Jim et al., 2006; Froehle et al., 2010). Given the variation in $C_{3}$ and $C_{4}$ resource use across our study area, variable discrimination factors may ultimately be warranted, but we chose to use static values for the sake of simplicity; in the absence of 
experimental estimates for the localities in our study, this is also the most parsimonious choice. Finally, we did not explicitly consider the isotopic routing of dietary protein to bone collagen in the models. Instead, we assume that bone collagen $\delta^{13} \mathrm{C}$ and $\delta^{15} \mathrm{~N}$ values are derived from dietary protein. Our mixing model results, therefore, are quantitative estimates of the proportional contribution of various plant and animal resources to human dietary protein. Because dietary routing may vary with the protein content of the diet (e.g. Schwarcz 2001; Martinez del Rio 2009; Newsome et al. 2011) it will be important to consider this issue in further investigations.

It is important to note, we have analysed representative samples of all potential food sources found during excavation, however we cannot rule out the possibility that other food sources were consumed but were not present in the archaeological record. As $\delta^{13} \mathrm{C}$ and $\delta^{15} \mathrm{~N}$ values are not currently available from archaeological plant material in Kazakhstan, so for those sites, we used values from western China; this decision involves significant assumptions, which we address in the results section.

\section{Results}

Figure 2 and Table 3 summarize the results of the mixing models performed on six sites in southern Kazakhstan and western China. Model performance varied from site to site. In western China, the model shows the most certainty in Wuba, with all six possible dietary sources exhibiting constrained uncertainties (see Figure 2, the boxplots show Bayesian 95\% credible intervals). Wheat and barley were less well constrained for Huoshaogou, in part because they were negatively correlated (0.62), meaning that the model could not easily discern between the sources; model solutions that favored wheat excluded barley and vice-versa. This was also true for wheat at Ganguai, which was negatively correlated with all of the other sources, but particularly strongly with Sus/Bos (-0.85) and millet (-0.76). The best-constrained results from Kazakhstan were for Karatuma (see Figure 2). Nonetheless, domestic animals from Karatuma were negatively correlated with several other sources at 
Kainar-Bulak-I (-0.55 with cervus, -0.52 with canids, and -0.43 with the Fertile Crescent cereals), making it difficult for the model to distinguish the difference among them in dietary contributions. The Fertile Crescent crops and caprines were strongly negatively correlated (-0.87) at Oi-Dzailau as well as Karatuma (domestic animals and $C_{3}$ crops: -0.98), though millet was very well constrained at that site.

In terms of the proportion (Bayesian 95\% credible intervals), $\mathrm{C}_{4}$ protein (likely millet) in human diets became significant in the Bronze and Iron Ages in southern Kazakhstan. At a population level, millet(s) comprises approximately $10-35 \%$ of dietary protein at Oi-Dzailau-VII (1600-1400 BC), about 20-25\% in Karatuma (400200 BC), and 35-50\% at Kainar Bulak-I (200 BC-300 AD). In China, the millet contribution to dietary protein falls during the Bronze Age from approximately 80$85 \%$ at Wuba (2450-1950 BC) to $35-55 \%$ at Huoshaogou (1900-1300 BC) to just 2$20 \%$ at Ganguai (1350-950 BC). In addition to the uncertainties outlined above, these estimated proportions also reflect the individual differences within a community. For example, at Oi-Dzailau-VII, two individuals that are mostly enriched and depleted in ${ }^{13} \mathrm{C}$ were selected for further analyses (see Table $\mathrm{S} 1$ for individual proportional dietary contributions; individuals selected for analyses are indicated in Figure 2). In individual $X\left(\delta^{13} \mathrm{C}: 8.8 \%, \delta^{15} \mathrm{~N}\right.$ : $\left.22.5 \% 0\right)$, millet contributed to approximately $0-10 \%$ of dietary protein; and in individual $\mathrm{Y}\left(\delta^{13} \mathrm{C}: 8.8 \%, \delta^{15} \mathrm{~N}\right.$ : $22.5 \%$ ), the figure is about $30-50 \%$.

The people of southern Kazakhstan and western China also diverge in their reliance on animal versus plant protein. In southern Kazakhstan, animal protein makes up the largest proportion of the protein component of human diets in the second millennium BC, comprising between approximately 35 and $80 \%$ at Oi-Dzailau-VII. This resource probably remained important in the first millennium BC at Karatuma $(\sim 60$ to $70 \%)$ and at Kainar-Bulak I. When all animal resources are considered together, animal protein is as important as millet in Kainar-Bulak I (approximately $40 \%$ of the dietary protein input). In contrast, millet is the principal food resource for the inhabitants of Wuba, comprising more than $80 \%$ of human diets there. In 
later periods wheat and/or barley gain significance - at Huoshaogou (averaging at about $15 \%$ and $25 \%$, respectively) and at Ganguai, wheat becomes the most important food resource (more than $30 \%$ on average) followed most closely by Sus/Bos group (about $20 \%$ on average). In all three cases, cereals contribute the most protein to human diets in China.

One problem with the Karatuma model is that the human data do not plot within the mixing space created by the possible food sources. This suggests that an important food resource was not available for isotopic analysis (e.g. freshwater fish and/or wild plants; Ventresca Miller et al. 2014) and/or the discrimination factors used were incorrect. Nonetheless, the result that terrestrial animal protein comprised the primary dietary protein intake for individuals from this site is consistent with previous work (Ventresca Miller et al., 2014).

Two issues are worth consideration. The sample size of the plant data is very small, so variations within the same crop are not fully captured. Our results therefore offer quantitative predictions as to the importance of these food sources to human diets that we hope will be tested as more data become available. More importantly, these results are dependent on isotope values for millet and barley from China. This is because, to the best of our knowledge, there are hitherto no published isotope data for either modern or archaeological millet and barley from Kazakhstan. Plant $\delta^{15} \mathrm{~N}$ values are related to multiple factors, such as the availability of nutrients and water, and can therefore vary significantly geographically, so values from China may be poor approximations for Kazakhstan. For example, possible explanations for the high $\delta^{15} \mathrm{~N}$ values of the Chinese millets could be manuring or aridity. Another study looking at stable isotope values in archaeological plant remains of Bronze Age samples from the Eurasian Caspian Steppe, to the east of Kazakhstan, found average ${ }^{13} \mathrm{C}$ values for $\mathrm{C}_{3}$ and $\mathrm{C}_{4}$ plants of $-26 \%$ and $-12 \%$, respectively (Shishlina et al., 2012). $\delta^{15} \mathrm{~N}$ values of Lithospermum officinale seeds ranged from 9.6 to $13.0 \% 0$ and amaranth seeds had a value of $6.4 \%$. To investigate how the mixing model results might change if millet values from Kazakhstan have much lower $\delta^{15} \mathrm{~N}$ values than 
those found in China, we ran the models for Oi-Dzailau, Karatuma and Kainar-Bulak with an arbitrary value of 3\%o instead of 9.4\%o. At Oi-Dzailau, this lower nitrogen isotope value model predicts that millet still contributes a mean value of $19 \%$ compared to $24 \%$ in the original model, but the confidence intervals are larger (830\%). For Karatuma, there is no change in the results; millet still makes up 19 $25 \%$ of the diet. And finally, at Kainar-Bulak millet contribution also stays approximately the same (decreases slightly in importance from a mean value of $44 \%$ to $42 \%$ ). These results suggest that the carbon isotope value is the primary driver, which makes sense, given that this is a concentration weighted model and digestible [N] from plants is much smaller than from animal food sources. Regardless, the pattern of increasing reliance on millet over time holds.

\section{Discussion}

Rapid adoption of wheat/barley and delayed millet consumption

The results of the mixing models confirm the dietary shifts previously documented in both regions (Liu et al., 2014; Motuzaite Matuzeviciute et al., 2015a). A few aspects are worth further consideration. There was a considerable delay between the earliest evidence for millet grains and the adoption of millet as a substantial food resource in southeast Kazakhstan. The earliest archaeobotanical evidence of millet (from Begash) precedes the first carbon isotopic evidence of substantial millet consumption (from Oi-Dzailau-VII) by a few centuries. It is worthy of note, however, that all of the isotopic evidence to date post-dates the archaeobotanical evidence from Begash. Stable isotope analysis is relatively insensitive to minor dietary components; thus the isotopic indication of millet consumption at Oi-Dzailau suggests that some individuals consumed significant quantities of millet and others did not. Our model estimates that on average millet contributes approximately 10$35 \%$ of the dietary protein. Nonetheless, this eating habits various according to individuals; in Oi-Dzailau, some consumed millet as $30-50 \%$ dietary protein source, others consumed almost none. 
This pattern is in contrast to that observed in western China, where the earliest archaeobotanical evidence for the presence of $\mathrm{C}_{3}$ cereals (primarily wheat and barley) in Gansu is archaeologically approximately contemporaneous with isotopic evidence for the large-scale consumption of $\mathrm{C}_{3}$ plant resources in early the second millennium BC. Our data show that wheat and barley contributes about 40\% (mean value) of the dietary protein in Huoshaogou and Ganguai, indicating that Fertile Crescent crops were consumed in significant quantities concurrent with or soon after their first appearance in this region. Although the proportion varies, all individuals from Huoshaogou and Ganguai had comsumed $\mathrm{C}_{3}$ grains directly. This would support the argument that the Fertile Crescent crops were moved and/or adopted in order to provide a new staple foodstuff to the people.

The delay of isotopically detectable millet consumption in Kazakhstan, on the other hand, suggests its initial introduction as a minor component of human diets. One interpretation is that millet was not first introduced to Central Asia as a staple food, but for other reasons, perhaps ritual use or as an indictor of wealth or status. Indeed, some of the earliest evidence of millet was from a burial context rather than from a settlement, indicating that it may well have had a special significance beyond subsistence. Frachetti (2015), for example, argued that the crop remains from Begash, were the 'seeds for the soul'. It could be the case that some foodstuffs would be specifically associated with special ritual events, such as the key life history rites de passage. Nonetheless, these events typically emphasize timelessness and ancestry, and do not offer an immediate conceptual link with either novel or normal cereal grains. It is also entirely possible that millet was exploited as a risk reduction strategy or in the context of a seasonal mobility model. Thus, there are a variety of reasons why an introduced crop may remain a minor component of the diet, and we currently lack the full range of contextual evidence necessary to infer the most plausible reason in this case. 
Our data also reveal different strategies of consumption of dietary animal protein. Contemporary people in Kazakhstan and western China diverge in their reliance on animal versus plant protein. Animal protein derived from domestic animals or game consistently made a substantial contribution to human diets in Kazakhstan. In western China, on the other hand, while meat consumption increased relatively in the period after $1900 \mathrm{BC}$, various crops (either $\mathrm{C}_{3}$ or $\mathrm{C}_{4}$ ) were consistently the most important food resource for the population in this region. The dietary shift documented in Gansu was probably connected with the direct consumption of wheat and barley.

Our data allows us to contrast the dietary situations at each end of the 'Mountain Corridors', i.e. the Hexi Corridor and southern Kazakhstan. In between the two regions lies Xinjiang (Xinjiang Uyghur Autonomous Region). Human isotopic values from several sites in this region have been published (Zhang and Li, 2006; Zhang et al., 2009; Zhang et al., 2010; Zhang and Zhu, 2011). The current evidence suggests that the dietary choices in Xinjiang vary from community to community during the second millennium BC. It is seemingly the millet consumers lived side by side with communities consumed more meat and $\mathrm{C}_{3}$ foodstuff and less millet. Published isotopic values derived from animal remains are limited at the moment however. Future isotopic research to combine human and animal data may be anticipated.

\section{Agencies of translocations of wheat/barley and millet}

The gradual adoption of millet in southern Kazakhstan serves to highlight the rapidity of the adoption of wheat and barley in west China. During the second millennium BC, wheat and barley were both growing in the fields and being widely consumed in significant quantities in Gansu, constituting a revolution in eating habits. By contrast, the first appearance of millet currently pre-dates the isotopic evidence of consumption on a significant scale in Kazakhstan. 
Liu et al. (2014) argued that the rapid adoption of wheat and/or barley in Gansu could be understood in the context of social and ecological challenges in relation to the expansion of human settlement to arid northwest China. In Gansu, the global drought event of the time was complicated by a widespread weakening of the summer monsoon between 2500 and 2000 BC (An et al., 2005a; An et al, 2005b). A plausible explanation of the rapid dietary change in this region is that the early colonizers faced a series of ecological and social challenges: the threat of challenging environments; the threat of famine; and population pressure in spatially limited arable lands. In the face of such challenges, conservative food choices may simply not have been sustainable. In addition, the data lend support to the argument that wheat and/or barley were initially introduced to northwest China as a new staple food to serve the needs of the poor majority, rather than to the rich minority.

By contrast, dietary conservatism may be more in evidence elsewhere. In Kazakhstan, although the archaeobotanical evidence indicates that millet was present from the late third millennium $\mathrm{BC}$, the current isotopic evidence suggests that millet was not consumed on a significant scale until almost a few hundred years later. In the later case, the newly developed millet eating habits various according to individuals. The individual variation and the time lag between the initial introduction of millet and its subsequent consumption on a significant scale, could be explained by the initial use being connected with a minority, for example elites, ritual specialists, or seasonal mobile groups.

\section{Conclusion}

In this paper we apply Bayesian stable isotope mixing models to published and newly obtained isotopic data in order to quantitatively estimate the contribution of different food resources to human diets; and we consider the complexity of human food strategies at the both ends of the mountain corridors: southern Kazakhstan and the Hexi corridor in western China. Our results contrast the rapid adoption of wheat and/or barley in the Hexi Corridor with the gradual, incremental adoption of millet 
in southern Kazakhstan during the second millennium BC. The people who lived in the Hexi Corridor consumed wheat and/or barley on a considerable scale shortly after the crops were introduced into the region. In Kazakhstan, millet consumption is not isotopically detectable until around a few hundred years after the first archaeobotanical evidence from the region. In addition, the people in southern Kazakhstan and western China diverge in their reliance on animal, as opposed to plant, protein. These patterns are best explained as different driving forces facilitating the eastward expansion of the Fertile Crescent crops and westwards expansion of millet.

\section{Acknowledgement}

The authors are grateful to European Research Council, under grant 24964 (FOGLIP), Washington University Deanery Office Grant, American Association of University Women (AAUW), International Center for Advanced Renewable Energy and Sustainability (I-CARES) for financial support. We are thankful to Catherine Kneale and James Rolfe from Cambridge for assistance with isotopic analysis. We are also grateful to Pavel Tarasov for helps to the manuscript; and to Professors Mayke Wagner and Pavel Tarasov and Dr Robert Spengler for organizing the workshop, entitled 'The Introduction and Intensification of Agriculture in Central Eurasia', Berlin in 2015.

\section{References}

Ambrose SH and Norr L (1993) Ecperimental evidence for the relationship of the carbon isotope ratios of whole diet and dietary protein to those of bone collagen and carbonate. In: Lambert JB and Grupe G (eds) Prehistoric Human Bone: Archaeology at the Molecular Level. Berlin: Springer-Verlag, 1-37.

An C, Tang L, Barton L et al. (2005a) Climate change and cultural response around $4000 \mathrm{cal}$ yr B.P. in the western part of Chinese Loess Plateau. Quaternary Research 63.

An C-B, Feng Z-D and Barton L (2005b) Dry or humid? Mid-Holocene humidity changes in arid and semi arid China. Quaternary Science Reviews 25: 351-361. 
Barton L and An C-B (2014) An evaluation of competing hypotheses for the early adoption of wheat in East Asia. World Archaeology 46: 775-798.

Boivin N, Fuller D and Crowther A (2012) Old World globalization and the Columbian exchange: comparison and contrast. World Archaeology 44: 452469.

Castillo C (2011) Rice in Thailand: the archaeobotanical contribution. Rice 4: 114120.

Chen F-H, Dong F-H, Zhang D-J et al. (2014) Agriculture facilitated permanent human occupation of the Tibetan Plateau after 3600BP. Science 347: 248250.

Costantini L (1984) The beginning of agriculture in the Kachi Plain: the evidence of Mehrgarh. In: Allchin B (ed) South Asian Archaeology. Cambridge: Cambridge University Press, 29-33.

Flad R, Li S, Wu X et al. (2010) Early wheat in China: results from new studies at Donhuishan in the Hexi Corridor. the Holocene 17: 555-560.

Frachetti MD (2008) Pastoralist Landscape and Social Interaction in Bronze Age Eurasia, Berkeley: University of California Press.

Frachetti MD (2012) Multiregional emergence of mobile pastoralism and nonuniform institutional complexity across Eurasia. Current Anthropology 53: 2-38.

Frachetti MD, Spengler RN, Fritz GJ et al. (2010) Earliest direct evidence for broomcorn millet and wheat in the central Eurasia steppe region. Antiquity 84: 993-1010.

Froehle AW, Kellner CM and Schoeninger MJ (2010) FOCUS: effect of diet and protein source on carbon stable isotope ratios in collagen: follow up to Warinner and Tuross (2009). Journal of Archaeological Science 37: 26622670.

Guan L, Hu Y, Tang Z et al. (2007) Tonghua Wanbazi yizhi zhugu de C, N wending tongweisu fenxi (Stable isotopic analysis on sus bones from the Wanfabazi site, Tonghua, Jilin). Kexue Tongbao (Chinese Science Bulletin) 52: 3393-3396.

Hare PE, Fogel ML, Stafford TW et al. (1991) The isotopic composition of carbon and nitrogen in individual amino-acids isolated from modern and fossil proteins. Journal of Archaeological Science 18: 277-292.

Harris D (2010) Origins of Agriculture in Western Central Asia, Philadelphia: University of Pennsylvania Museum.

Hedges REM and Reynard LM (2007) Nitrogen isotopes and the trophic level of humans in archaeology. Journal of Archaeological Science 34: 1240-1251.

Hunt HV, Linden MV, Liu X et al. (2008) Millets across Eurasia: chronology and context of early records of the genera Panicum and Setaria from archaeological sites in the Old World. Vegetation History and Archaeobotany 17: 5-18.

Jim S, Jones V, Ambrose SH et al. (2006) Quantifying dietary macronutrient sources of carbon for bone collagen biosynthesis using natural abundance stable carbon isotope analysis. British Journal of Nutrition 95: 1055-1062. 
Jones MK, Harriet H, Kneale CJ et al. (in press) Food Globalisation in PrehistoryL the agrarian foundation of an interconnected continent. Journal of the British Academy.

Jones MK, Hunt HV, Lightfoot E et al. (2011) Food globalization in prehistory. World Archaeology 43: 665-675.

Koch PL and Phillips DL (2002) Incorporating concentration dependence in stable isotope mixing models: a reply to Robbins, Hilderbrand and Farley (2002). Oecologia 133: 14-18.

Lee-Thorp JA, Sealy JC and Van der Merwe MJ (1989) Stable carbon isotope ratio differences between cone collagen and bone apatite and their relationsip to diet. Journal of Archaeological Science 18: 343-354.

Levine M (1999) Late Prehistoric Exploitation of the Eurasian Steppe, Cambridge: McDonald Institute for Archaeological Research.

Lightfoot E, Liu X and Jones MK (2013) Why move starchy cereals? a review of the isotopic evidence for prehistoric millet consumption across Eurasia. World Archaeology 45: 574-623.

Lightfoot E, Motuzaite-Matuzeviciute G, O'Connell TC et al. (2014) How 'pastroal' is pastoralism? Dietary diversity in Bronze Age communities in the central Kazakhstan steppes. Archaeometry 57: 232-249.

Lin M-C (2015) Saiyima-Tubinnuo wenhua yu shiqian sichou zhilu (Seima-Turbino and prehistoric silk road). Wenwu (Cultral Relics) 10: 49-63.

Linduff KM and Mei J (2009) Metallurgy in ancient Eastern Asia: Retrospect and prospects. Journal of World Prehistory 22: 265-281.

Liu X, Fuller D and Jones MK (2015) Early agriculture in China. In: Barker G and Goucher C (eds) The Cambridge World History - Volume II: A world with agriculture, 12,000 BCE-500CE. Cambridge: Cambridge University Press, 310334.

Liu X, Hunt HV and Jones MK (2009) River valleys and foothills: changing archaeological perceptions of north China's earliest farms. Antiquity 83: 8295.

Liu X and Jones MK (2014) Food globalisation in prehistory: top down or bottom up? Antiquity 88: 956-963.

Liu X, Lightfoot E, O'Connell TC et al. (2014) From necessity to choice: dietary revolutions in west China in the second millennium BC. World Archaeology 46: 661-680.

Liu X, Lister DL, Zhao Z-Z et al. (in press) The virtues of small grain size: Potential pathways to a distinguishing feature of Asian wheats. Quaternary International: doi.org/10.1016/j.quaint.2016.1002.1059.

Ma M, Dong G, Liu X et al. (2013a) Stable isotope analysis of human and animal remains at the Qijiaping site in middle Gansu, China. International Journal of Osteoarchaeology published online.

Ma MM, Dong GH, Lightfoot E et al. (2013b) Stable isotope analysis of human and faunal remains in the western loess plateau, approximately $2000 \mathrm{cal}$. BC. Archaeometry.

Martínez del Rio C, Wolf N, Carleton SA et al. (2009) Isotopic ecology ten years after a call for more laboratory experiments. Biological Reviews 84: 91-111. 
Meadow RH (1996) The origins and spread of agriculture and pastoralism in north western South Asia. In: Harris D (ed) The Origins and Spread of Agriculture and Pastoralism in Eurasi. London: UCL Press, 390-412.

Mei J (2003) Qijia and Seima-Turbino: the question of early contacts between Northwest China and Eurasian Setppe. The Museum of Far Eastern Antiquities - Bulletin No. 75. Stockholm: The Museum of Far Eastern Antiquities, 31-55.

Miller NF (2003) The use of plants at Anau North. In: Hiebert FT and Kurdansakhatov $\mathrm{K}$ (eds) A Central Asian village at the dawn of civilization: Excavations at Anau, Turkmenistan. Philadelphia: University of Pennsylvania Museum.

Motuzaite Matuzeviciute G, Lightfoot E, O'Connell TC et al. (2015a) The extent of agriculture among pastoralist societies in Kazakhstan using stable isotope analysis of animal bone. Journal of Archaeological Science 59: 23-24.

Motuzaite Matuzeviciute G, Staff RA, Hunt HV et al. (2013) The early chronology of broomcorn millet (Panicum miliaceum) in Europe. Antiquity 87: 1073-1085

Motuzaite Matuzeviciute GM, Preece RC, Wang S et al. (2015b) Ecology and subsistence at the Mesolithic and Bronze Age site of Aigyrzhal-2, Naryn valley, Kyrgystan. Quaternary International: Available online 18 August 2015 - doi:2010.1016/j.quaint.2015.2006.2065.

Murphy EM, Schulting RJ, Beer N et al. (2013) Iron Age pastoral nomadism and agriculture in the Eastern Earasian Steppe: Implications from dental palaeopathology and stable carbon and nitrogen isotopes. Journal of Archaeological Science 40: 2547-2560.

Newsome SD, Fogel ML, Kelly MJ et al. (2011) Contributions of direct incorporation from diet and microbial amino acids to protein synthesis in Nile tilapia. Functional Ecology 25: 1051-1062.

Newsome SD, Phillips DL, Culleton BJ et al. (2004) Dietary reconstruction of an early to middle Holocene human population from the central California coast: insights from advanced stable isotope mixing models. Journal of Archaeological Science 25: 1051-1062.

Parnell AC, Inger R, Bearhop S et al. (2010) Source Partitioning Using Stable Isotopes: Coping with Too Much Variation. PLoS ONE 5: e9672.

Petrie CA (2015) Mehgarh, Pakistan. In: Barker G and Goucher C (eds) The Cambridge World History Volume II - A World with Agriculture, 12000 BCE500 CE. Cambridge: Cambridge University Press, 289-309.

Phillips DL, Inger R, Bearhop S et al. (2014) Best practices for use in stable isotope mixing models in food-web studies. Canadian Journal of Zoology 92: 823-835.

Phillips DL and Koch PL (2002) Incorporating concentration dependence in stable isotope mixing models. Oecologia 130: 114-125.

Rawson J (2013) Ordering the exotic: Ritual practices in the late Western and early Eastern Zhou. Artibus Asiae 73: 5-24.

Schoeninger MJ (1985) Trophic level effects on $15 \mathrm{~N} / 14 \mathrm{~N}$ and $13 \mathrm{C} / 12 \mathrm{C}$ ratios in bone collagen and strontium levels in bone mineral. Journal of Human Evolution 14: 515-525. 
Schwarcz HP (2002) Some biochemical aspects of carbon isotopic paleodiet studies. In: Ambrose SH and Katzenberg MA (eds) Biogeochemical Approaches to Paleodietary Analysis. New York: Kluwer Academic/Plenum Publishers.

Sherratt A (2005) The Trans-Eurasian exchange: the prehistory of Chinese relations with the West. In: Mair V (ed) Contact and Exchange in the Ancient World. Honolulu: Hawaii University Press, 30-61.

Shishlina N, Sevastyanov V and Hedges REM (2012) Isotope ratio study of Bronze Age samples from the Eurasian Caspian Steppes. In: Kaiser E, Burger J and Schier W (eds) Population Dynamics in Prehistory and Early History. New Approaches by Using Stable Isotopes and Genetics. Berlin and Boston: De Gruyter, 177-197.

Spengler R, Frachetti M, Doumani P et al. (2014a) Early agriculture and crop transmission among Bronze Age mobile pastoralists of Central Eurasia. Proceedings of the Royal Society B: Biological Sciences 281: 1-7.

Spengler RN (2015) Agriculture in the Central Asian Bronze Age. Journal of World Prehistory 28: 215-253.

Spengler RN, Frachetti MD and Domani PN (2014b) Late Bronze Age agriculture at Rasbas in the Dzhungar Mountains of eastern Kazakhstan. Quaternary International 348: 147-157.

Spengler RN and Willcox G (2013) Archaeobotanical results from Sarazm, Tajikistan, an Early Bronze Age Settlement on the edge: Agriculture and exchange. Journal of Environmental Archaeology 18: 211-221.

Svyatko SV, Schulting RJ, Mallory J et al. (2013) Stable isotope sietary analysis of prehistoric populations from the Minusinsk Basin, Southern Siberia, Russia: a new chronological framework for the introduction of millet to the eastern Eurasian steppe. Journal of Archaeological Science 40: 3936-3945.

Ventresca Miller A, Usmanova E, Logvin V et al. (2014) Subsistence and social change in Central Eurasia: stable isotope analysis of populations spanning the Bronze Age transition. Journal of Archaeological Science 42: 525-538.

Wagner M, Tarasov P, Hosner D et al. (2012) Mapping of the spatial and temporal distribution of archaeological sites of northern China during the Neolithic and Bronze Age. Quaternary International 290-291: 344-357.

Webber SA (1991) Plants and Harappan subsistence: an example of stability and change from Rojdi. Boulder: Westview Press.

Webber SA (2001) Ancient seeds: their role in understanding South Asia and its past. In: Ford R (ed) Ethnobiology at the Millennium, Past Promise and Future Prospects. Michigan: Ann Arbor: Museum of Anthropology, University of Michigan.

Weiss E and Zohary D (2011) The Neollithic Southwest Asian Founder Crops: Their biology and archaeobotany. Current Anthropology 52: S237-S254.

Yang X, Wan Z, Perry L, et al. (2012) Early millet use in northern China. Proc.Natl. Acad. Sci. U.S.A. 109: 3726-3730.

Zhang G, Wang S, Ferguson DK et al. (2015) Ancient plant use and palaeoenvironmental analysis at the Gumugou Cemetery, Xinjiang, China: implication from desiccated plant remains. Archaeological and 
Anthropological Sciences: published online: DOI 10.1007/s12520-1201510246-12523.

Zhang Q, Chang X and Liu G (2009) Xinjiang Balikun xian Heigouliang mudi chutu rengu de shixing fenxi (Stable isotopic analysis on human bones from Heigouliang cemetery in Barkol, Xinjiang). Xiyu Yanjiu (the Western Regions Studies) 3: 45-49.

Zhang Q, Chang X and Liu G (2010) Xinjiang Hami Tianshanbeilu mudi chutu rengu de wending tongweisu fenxi (Stable isotopic analysis of humanbones unearthed from Tianshan Beilu cemetery in Hami, Xinjiang). Xiyu Yanjiu (the Western Regions Studies) 2: 38-43.

Zhang Q and Li S (2006) Xinjiang Nileke Xian Kongkeke yihao mudi gudai jumin de shiwu jiegou fenxi (Analysis on paleodiet of ancient inhabitants in no. 1 cemetery of Qiongkeke at Nika County, Xinjiang). Xiyu Yanjiu (the Western Regions Studies) 4: 78-82.

Zhang Q and Zhu H (2011) Xinjiang Gumugou mudi rengu de wending tongweisu fenxi: zaoqi Luobubo xianmin yinshi jiegou chutan (Stable isotopic analysis on human bones from Gumugou cemetery, Xinjiang: paleodietary reconstruction on Luobubo population). Хiyu Yanjiu (the Western Regions Studies) 3: 91-96.

Zhou L and Garvie-Lok SJ (2015) Isotopic evidence for the expansion of wheat consumption in northern China. Archaeological Research in Asia 4: 25-35. 


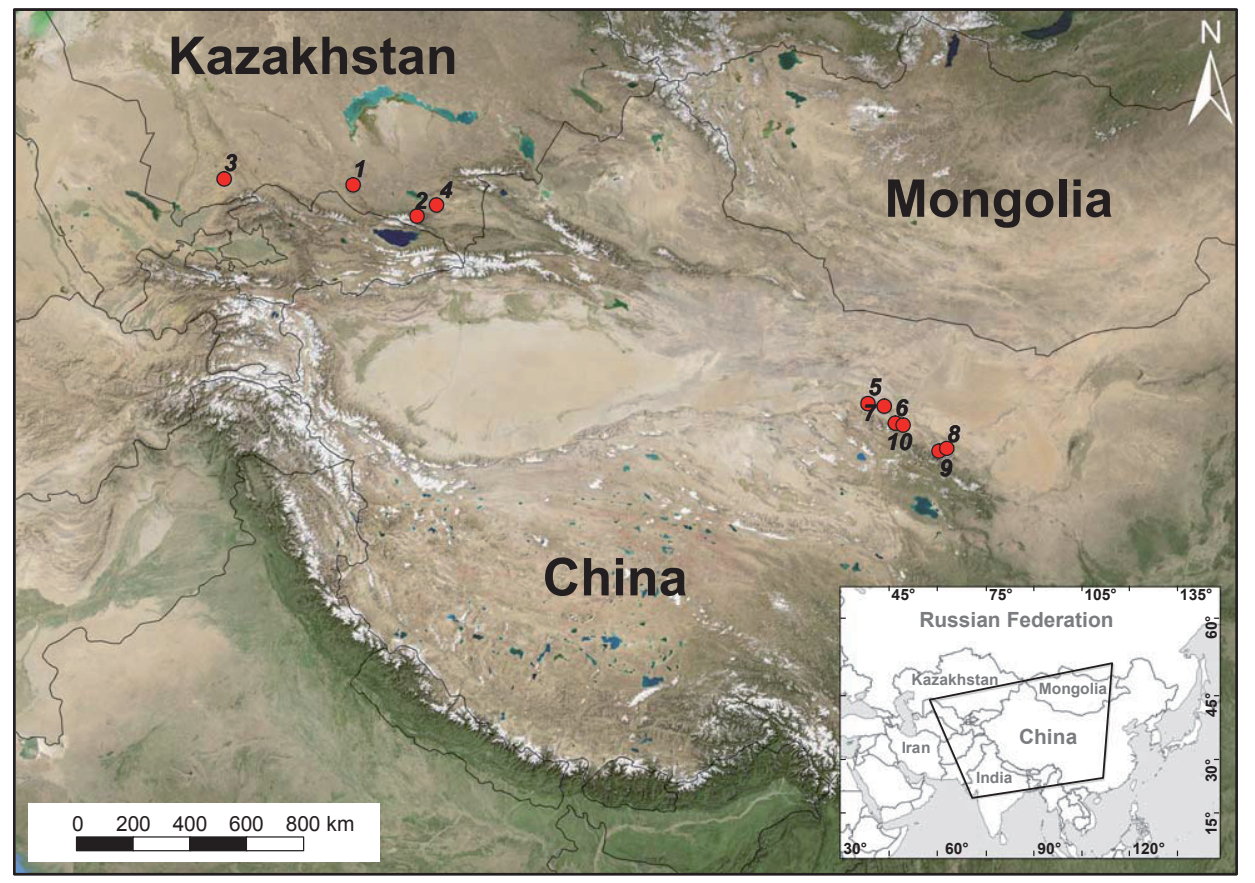

Figure 1. Maps showing location and topography of the study region and the sites from Kazakhstan and China discussed in this paper (see Table 1 for detailed information). 1 - Oi-Dzailau VII, 2 - Kyzyl Bulak I, 3 - Kainar Bulak, 4 - Karatuma, 5 Huoshaogou, 6 - Ganguai, 7 - Sanbadongzi, 8 - Donghuishan, 9 - Wuba, 10 Xihetan. 

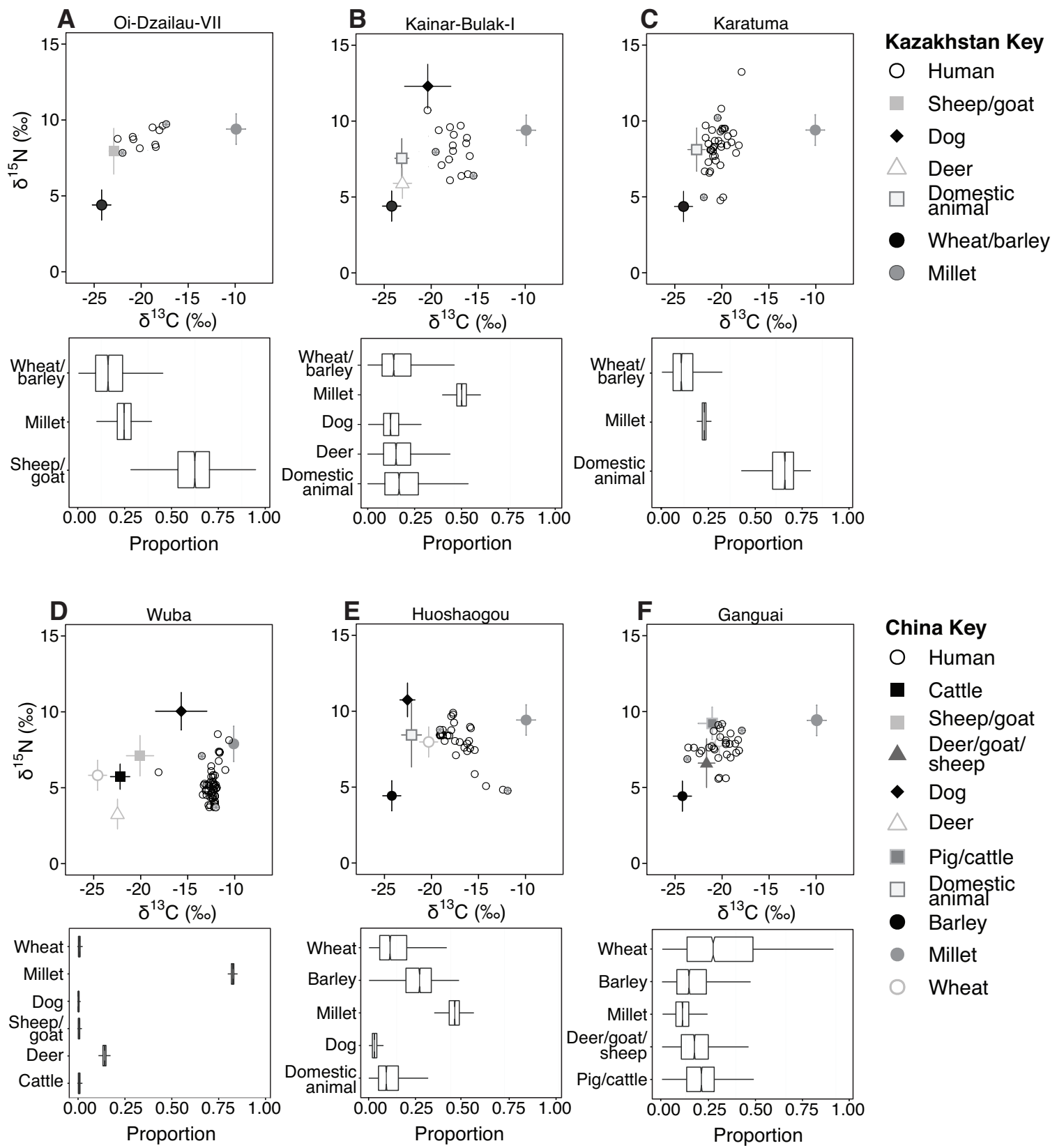

Figure 2. Summary of stable isotope data input into the mixing models and the mixing model results for sites in Kazakhstan (upper panel) and China (lower panel). Within each panel, sites are ordered from oldest (left) to youngest (right). The results are labeled as where human bones are recovered. Diet composition data are drawn from the nearest possible locations (see Table 1 and Table 2 for details). 
Table 1. Site information derived from Liu et al. (2014) and Motuzaite Matuzeviciute et al. (2015). A star $\left(^{*}\right)$ indicates age intervals based on radiocarbon determinations from human bones, while no star implies ages based on cultural context. ' $n$ ' is the number of radiocarbon dates.

\begin{tabular}{|c|c|c|c|c|}
\hline Site & Region & Period & Cultural group & Age, years BC/AD \\
\hline Oi-Dzailau VII & S Kazakhstan & Late Bronze Age & Andronovo & $1600-1400 \mathrm{BC}^{*}(\mathrm{n}=2)$ \\
\hline Kyzyl-Bulak & S Kazakhstan & Late Bronze Age & Andronovo & $1750-1500 \mathrm{BC}^{*}(\mathrm{n}=2)$ \\
\hline Kainar Bulak-I & S Kazakhstan & Early Iron Age & Wusun/Hunic & $200 \mathrm{BC}-300 \mathrm{AD}^{*}(\mathrm{n}=2)$ \\
\hline Karatuma & S Kazakhstan & Early Iron Age & Wusun & $400-100 \mathrm{BC}^{*}(\mathrm{n}=3)$ \\
\hline Huoshaogou & W China & Bronze Age & Shanma/Siba & $1900-1300^{*}(\mathrm{n}=8)$ \\
\hline Ganguai & W China & Bronze Age & Siba & $1350-950 *(\mathrm{n}=1)$ \\
\hline Sanbadongzi & W China & Bronze Age & Siba & $1500-1000$ \\
\hline Wuba & W China & Bronze Age & $\begin{array}{l}\text { Banshan/Machang/Qijia/Transitional } \\
\text { type }\end{array}$ & $2450-1950^{*}(n=4)$ \\
\hline Xihetan & W China & Bronze Age & Qijia/Siba & $2300-1000$ \\
\hline
\end{tabular}

Table 2. Isotope and diet composition data used in modeling. We made the following assumptions about the isotope values of food sources and humans: (1) $\delta^{13} \mathrm{C}_{\text {muscle}}-\delta^{13} \mathrm{C}_{\text {collagen }}-4 \%$; ; (2) $\delta^{13} \mathrm{C}_{\text {diet }}=\delta^{13} \mathrm{C}_{\text {collagen }}-5 \%$; ; 3 ) $\delta^{15} \mathrm{~N}_{\text {diet }}=\delta^{15} \mathrm{~N}_{\text {collagen - }}$ $5 \%$ (Oi-Dzailau) or - 4\%o (all other sites). Digestible [C] and [N] were calculated using the USDA Nutrient Database following Koch and Phillips (2002). 'SD' stands for standard deviation; and ' $n$ ' stands for number of samples.

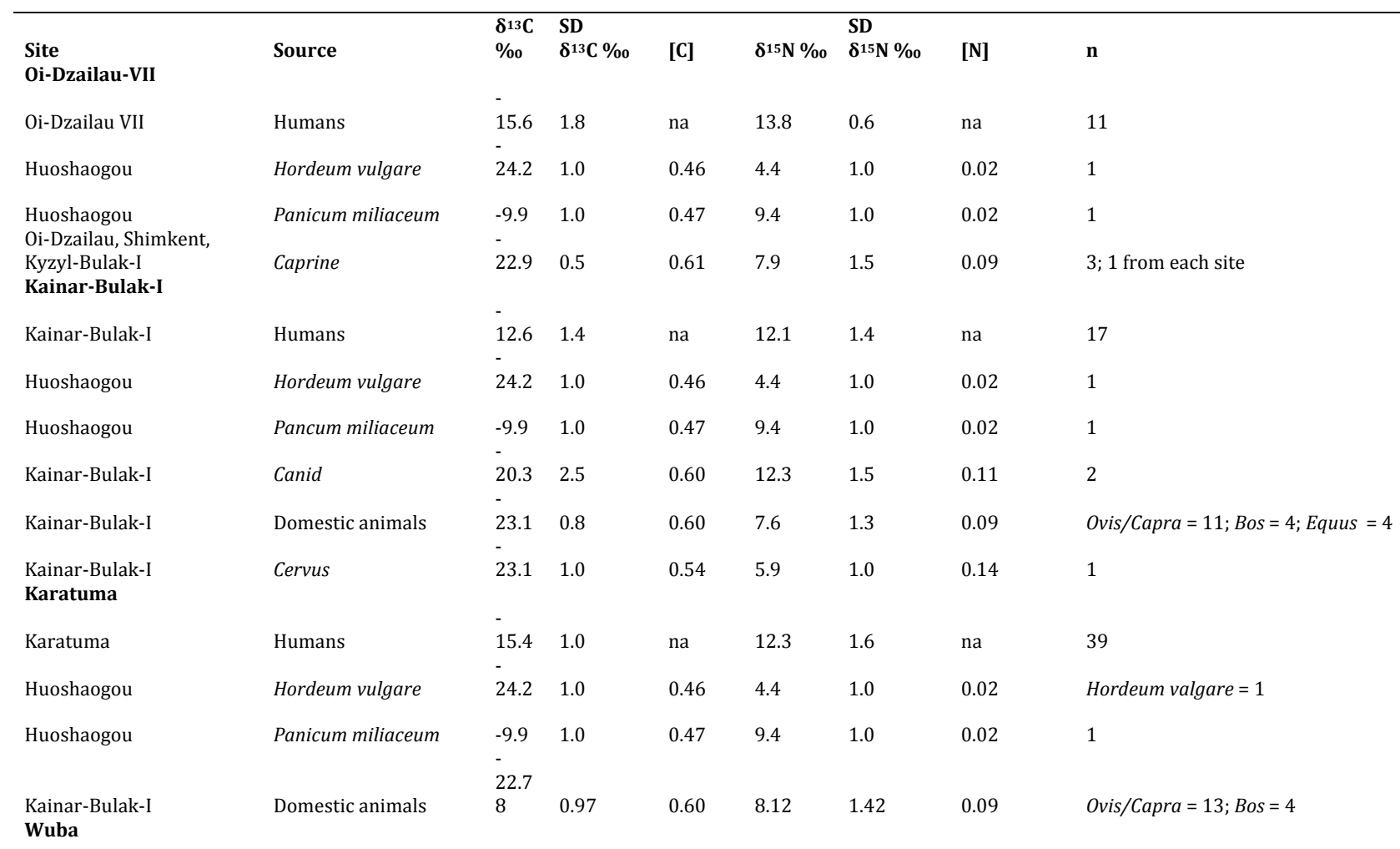




\begin{tabular}{|c|c|c|c|c|c|c|c|c|}
\hline Wuba & Humans & -7.4 & 0.9 & na & 9.2 & 1.1 & na & 56 \\
\hline Donghuishan & $\begin{array}{l}\text { Triticum eastivum } \\
\text { Setaria italic } \\
\text { /Panicum }\end{array}$ & -24.6 & 1.0 & 0.46 & 5.8 & 1.0 & 0.02 & 1 \\
\hline Donghuishan and Xihetan & miliaceum & -10.1 & 0.4 & 0.47 & 7.9 & 1.2 & 0.02 & Setaria italic $=2 ;$ Panicum miliaceum $=1$ \\
\hline Xihetan & Canid & -15.7 & 2.8 & 0.60 & 10.0 & 1.2 & 0.11 & 7 \\
\hline Xihetan & Bos & -22.2 & 1.1 & 0.61 & 5.7 & 0.8 & 0.09 & 7 \\
\hline Xihetan & Caprine & -20.1 & 1.5 & 0.61 & 7.1 & 1.3 & 0.09 & 14 \\
\hline Xihetan & Cervus & -22.5 & 0.3 & 0.54 & 3.3 & 1.0 & 0.14 & 5 \\
\hline \multicolumn{9}{|l|}{ Huoshaogou } \\
\hline Huoshaogou & Humans & $\begin{array}{l}12.0 \\
-\end{array}$ & 1.9 & na & 12.0 & 1.3 & na & 30 \\
\hline Huoshaogou & Triticum eastivum. & $\begin{array}{l}20.3 \\
-\end{array}$ & 1.0 & 0.46 & 8.0 & 1.0 & 0.02 & 1 \\
\hline Huoshaogou & Hordeum vulgare & 24.2 & 1.0 & 0.46 & 4.4 & 1.0 & 0.02 & 1 \\
\hline Huoshaogou & Panicum miliaceum & $\begin{array}{l}-9.9 \\
-\end{array}$ & 1.0 & 0.47 & 9.4 & 1.0 & 0.02 & 1 \\
\hline Huoshaogou & Canid & $\begin{array}{l}22.6 \\
-\end{array}$ & 0.8 & 0.60 & 10.7 & 1.1 & 0.11 & $\begin{array}{l}10 \\
\text { Ovis } / \text { Capra }=41 ; \text { Bos }=28 ; \text { Sus }=7 ; \text { Equus }\end{array}$ \\
\hline Huoshaogou & Domestic animals & 22.1 & 1.1 & 0.61 & 8.4 & 2.1 & 0.09 & $=4$ \\
\hline \multicolumn{9}{|l|}{ Ganguai } \\
\hline Ganguai & Humans & $\begin{array}{l}15.3 \\
-\end{array}$ & 1.5 & na & 11.6 & 0.9 & na & 30 \\
\hline Huoshaogou & Triticum eastivu & 20.3 & 1.0 & 0.46 & 8.0 & 1.0 & 0.02 & 1 \\
\hline Huoshaogou & Hordeum vulgare & 24.2 & 1.0 & 0.46 & 4.4 & 1.0 & 0.02 & 1 \\
\hline Huoshaogou & Panicum miliaceum & $\begin{array}{l}-9.9 \\
-\end{array}$ & 1.0 & 0.47 & 9.4 & 1.0 & 0.02 & 1 \\
\hline Sanbadongzi & Caprine/Cervus & $\begin{array}{l}21.7 \\
-\end{array}$ & 0.9 & 0.59 & 6.6 & 1.6 & 0.10 & Ovis $/$ Capra $=16 ;$ Cervus $=8$ \\
\hline Sanbadongzi & Sus/Bos & 21.1 & 1.5 & 0.63 & 9.2 & 1.1 & 0.07 & Sus $=10 ;$ Bos $=10$ \\
\hline
\end{tabular}

Table 3. Estimated proportional dietary contributions of various animal and plant food resources to archaeological humans with Bayesian credible intervals.

\begin{tabular}{|c|c|c|c|c|c|c|}
\hline \multirow[b]{2}{*}{ Site } & \multirow[b]{2}{*}{ Source } & \multirow[b]{2}{*}{ Mean } & \multicolumn{4}{|c|}{$95 \%$ credible interval } \\
\hline & & & SD & $2.5 \%$ & $97.5 \%$ & Range \\
\hline \multicolumn{7}{|c|}{ Oi-Dzailau-VII } \\
\hline & Wheat/barley & 0.17 & 0.10 & 0.02 & 0.39 & 0.37 \\
\hline & Millet & 0.24 & 0.06 & 0.13 & 0.36 & 0.23 \\
\hline & Sheep/goat & 0.59 & 0.12 & 0.35 & 0.79 & 0.44 \\
\hline & sd $\delta^{13} \mathrm{C}$ & 1.97 & 0.58 & 1.15 & 3.38 & \\
\hline & $\operatorname{sd} \delta^{15} \mathrm{~N}$ & 0.60 & 0.48 & 0.03 & 1.76 & \\
\hline \multicolumn{7}{|c|}{ Kainar-Bulak-I } \\
\hline & Wheat/barley & 0.14 & 0.10 & 0.02 & 0.37 & 0.35 \\
\hline & Millet & 0.44 & 0.03 & 0.37 & 0.50 & 0.13 \\
\hline & Dog & 0.11 & 0.05 & 0.03 & 0.22 & 0.19 \\
\hline & Domestic animals & & & & & \\
\hline & (Sheep/goat/cattle/horse) & 0.17 & 0.10 & 0.02 & 0.39 & 0.37 \\
\hline & Deer & 0.14 & 0.08 & 0.02 & 0.32 & 0.30 \\
\hline & $\operatorname{sd} \delta^{13} \mathrm{C}$ & 1.33 & 0.33 & 0.80 & 2.09 & \\
\hline & $\operatorname{sd} \delta^{15} \mathrm{~N}$ & 1.25 & 0.33 & 0.70 & 1.98 & \\
\hline \multicolumn{7}{|l|}{ Karatuma } \\
\hline & Wheat/barley & 0.12 & 0.08 & 0.02 & 0.31 & 0.29 \\
\hline & Millet & 0.23 & 0.02 & 0.20 & 0.26 & 0.06 \\
\hline & Domestic animals & & & & & \\
\hline & (Sheep/goat/cattle) & 0.65 & 0.08 & 0.45 & 0.76 & 0.32 \\
\hline & sd $\delta^{13} \mathrm{C}$ & 0.61 & 0.24 & 0.09 & 1.06 & \\
\hline & $\operatorname{sd} \delta^{15} \mathrm{~N}$ & 0.75 & 0.38 & 0.06 & 1.50 & \\
\hline \multicolumn{7}{|l|}{ Wuba } \\
\hline & Wheat & 0.01 & 0.01 & 0.00 & 0.03 & 0.03 \\
\hline
\end{tabular}




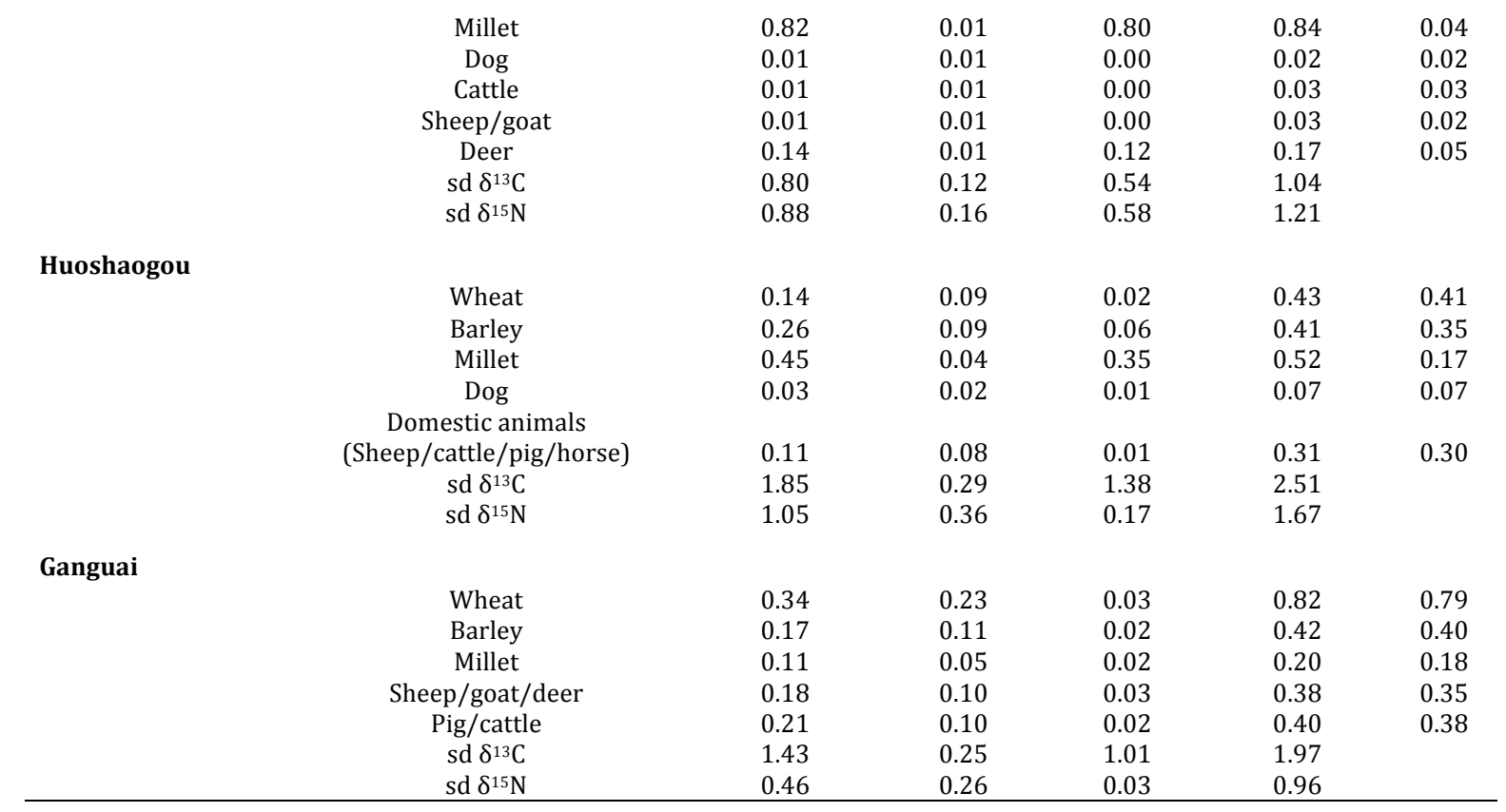

